\title{
Feed-in-Tariff Removal in UK's Community Energy: Analysis and Recommendations for Business Practices
}

\author{
Abhijeet Acharya ${ }^{1} \&$ Lisa A. Cave ${ }^{2}$ \\ ${ }^{1}$ College of Management and Technology, Walden University, Minnesota, USA \\ ${ }^{2}$ Faculty, College of Management and Technology, Walden University, Minnesota, USA \\ Correspondence: Abhijeet Acharya, College of Management and Technology, Walden University, Minnesota, \\ USA. E-mail: abhijeet.acharya@waldenu.edu
}

Received: June 9, $2020 \quad$ Accepted: June 26, $2020 \quad$ Online Published: July 132020

doi:10.5539/jsd.v13n4p1 URL: https://doi.org/10.5539/jsd.v13n4p1

\begin{abstract}
This paper aims to analyze the implications of Feed-In-Tariff (FIT) support removal in the UK's community energy sector and make recommendations for future business practices. European countries, including the UK, have recognized the critical role of Community Energy Cooperatives (CECs) in achieving low-carbon-energy transition targets through citizen engagements. However, due to the withdrawal of FIT support and other incentives in the UK, CECs struggle to sustain their profitability and growth. The subsidy-free, market-oriented policies have necessitated that CECs explore new business opportunities in collaboration with other actors of the business ecosystems. In this paper, we reviewed the impact of FIT support removal on community groups in the UK's member states, England, Scotland, and Wales. We analyzed effective business practices that CECs could follow to improve business viability and achieve growth. Based on our review, we make three recommendations for the business practices that can help CECs to remain profitable and grow in the UK's subsidy-free environment. We recommend that CECs 1) take part in shared ownership projects, 2) collaborate with local actors for bottom-up initiatives, and 3) explore low-interest financing models within the business ecosystem. The implication of findings from this paper includes new knowledge for CEC managers and policymakers in countries where the community energy sector is at a novice stage.
\end{abstract}

Keywords: community energy, energy transition, shared ownership, grassroots, energy policy, business ecosystem

\section{Introduction}

\subsection{Background}

Through citizen participation, Community Energy Cooperatives (CECs) set up local renewable energy systems to support climate change initiatives (Vancea, Becker, \& Kunze, 2017). Community energy groups use social entrepreneurial practices to address social and ecological issues at the grassroots level (Becker, Kunze, \& Vancea, 2017). There are approximately 3,000 community energy groups in Western Europe; the majority of which are based in Germany (over 1,100), the Netherlands (500), and the UK (400) (Hewitt et al., 2019; Koirala, Chaves Avila, Gómez, Hakvoort, \& Herder, 2016). CECs emerged during the 1990s, and in the initial stages, these community projects were limited in number while governments continued to focus on centralized energy systems based on fossil fuels and nuclear energy (Braunholtz-Speight et al., 2018; Strachan, Cowell, Ellis, Sherry - Brennan, \& Toke, 2015). However, the new century ushered in a period of social and political change. The 2000s were marked as a decade of political and social concern, with calls for policies to address the growing climate change concern. During this decade, the UK government enacted energy policies favorable to community energy projects, such as Feed-In-Tariff (FIT) schemes, which led to significant growth in the community energy sector (Eadson \& Foden, 2019).

The political landscape changed in the 2016 UK's national elections. These elections saw the rise of parties with neoliberalist ideologies supporting competitive open market energy policies (Braunholtz-Speight et al., 2018). The change in political landscape ultimately led to the UK government reversing its support for FITs and the withdrawal of other grants and subsidies for CECs. The UK government now viewed CECs as market-oriented community enterprises (Braunholtz-Speight et al., 2018). To encourage market-based practices, the UK 
government withdrew FITs and grants to urge CECs to participate in the open market (Eadson \& Foden, 2019). The UK reduced FITs and subsidies to CECs intending to empower them to grow as a self-sustaining enterprise (Green Alliance, 2019). However, the removal of FIT schemes, subsidies, and grants has severely impacted the development and growth of CECs (Braunholtz-Speight et al., 2018; Eadson \& Foden, 2019). Community Energy England (2019) reported 69 community projects were stalled in 2018 due to a reduction in FIT tariff and unfavorable policies.

The CEC evolution is guided by the principles of democratic governance and energy justice; vital characteristics of CECs is their engagement with community members related to renewable energy generation and distribution in their locality (Becker et al., 2017; Huybrechts \& Mertens, 2014). The removal of supports and market-focused energy policies has hampered CECs ability to survive and earn profits within the current energy regime. In particular, the consequences of market-focused energy policies on CECs include higher interest rates on project financing and barriers to entry in existing energy markets dominated by large incumbents (Community Energy England, 2019; Hall, Foxon, \& Bolton, 2016). Additionally, large incumbents with existing energy infrastructure and resources have a cost advantage and higher risk appetite in a market-based policy regime (Strachan et al., 2015). The high barriers to entry are further compounded by the difficulty CECs face in securing financing. In a market-based environment, financial institutions lack incentives to provide low-interest financing to CECs; therefore, CECs are likely to remain niche organizations unless there is a change in existing financing arrangements (Hall et al., 2016).

\subsection{Aim of the Paper}

This paper aims to review the implications of FIT support removal in the UK's community energy sector and make recommendations for business practices that CECs in the UK should consider to remain profitable and grow in the era of competitive market energy policies. The market-based energy regime has made it difficult for CECs to remain competitive due to higher interest rates on project financing, barriers to entry in existing energy markets, and cost disadvantages resulting from lower-scaled energy production. The UK's top-down energy policy based on neo-liberal ideas does not accommodate niche organizations in the decision-making process. We develop and discuss recommendations that CECs should consider to remain competitive. These recommendations include establishing business practices based on collaborations and partnerships that can help CECs improve their business viability in the subsidy-free environment. CECs must collaborate and partner with local actors of the ecosystem to create new business opportunities. Implementing a policy approach that is a mix of both top-down and bottom-up can help CECs achieve their full potential. A final recommendation is using collaborative approaches to gain access to innovative low-interest financing models. Additionally, the business concepts proposed in this paper can provide a foundation for future empirical investigation.

In section 1, we provided a brief background of FIT removal to CECs in the UK and discussed the aim of this paper. In section 2, we discussed the methodology used for this paper. In section 3, we described the emergence and current state of CECs, their roles and motives, organizational structures, and regional growth. We also discussed the problems and issues faced by CECs in the UK. Section 4 discusses the UK's community energy policy with a focus on FIT removal, rationale behind it, and regional response to FIT removal. In section 5, we discussed the implication of FIT removal and analyzed emerging business practices in the UK and Germany, and also, we made recommendations for business practices that are critical for the viability and growth of CECs in the UK. We concluded our paper in section 6 by highlighting the implications for CEC managers and community energy policymakers.

\section{Method}

This conceptual review is focused on the UK's community energy policy supports and the implications of FIT removal on business practices in the sector. The review also aims to identify new business concepts that CECs in the UK must explore post FIT removal to remain profitable and achieve growth. The emerging ideas proposed in this paper can provide a foundation for future empirical investigation. The conceptual review is the cornerstone for developing and clarifying theoretical concepts so that these concepts can be empirically tested at a later stage (Kahn \& Zeidler, 2017). A conceptual review's objective is to develop theoretical concepts through logical and convincing arguments rather than empirical testing (Gilson \& Goldberg, 2015). To form a conceptual basis, we conducted a literature review with a focus on the UK's energy policy and its implication on community energy business practices. Substantive literature reviews provide summaries, explain critical findings, and form the foundation for conceptual analysis (Cropanzano, 2009). This review was confined to secondary sources of information. The literature review covers papers related to the UK's community energy policies and their implications for CEC business practices published in the last five years. We also reviewed government 
publications and reports from intermediate organizations in the UK to understand the grassroots level challenges and issues. In the discussion section, we analyze successful business concepts in Scotland and Germany and discussed how such business practices could be applied in the UK's subsidy-free environment to enable CECs to achieve growth and remain profitable. Having discussed the method used for this review paper, in the following section, we discuss the elements of UK's community energy sector including 1) emergence and current state, 2) roles and motives, 3) organizational structure, 4) regional growth, and 5) problems and issues.

\section{Analysis of UK's CECs}

\subsection{Emergence and the Current State}

Similar to other European countries, the diffusion of community projects in the UK started in the 1990s. In the initial stages, these community initiatives were limited in numbers, while governments continued focusing on centralized energy systems based on fossil fuel and nuclear energy (Braunholtz-Speight et al., 2018; Strachan et al., 2015). However, the new century ushered in a period of social and political change. The 2000s were marked as a decade of political and social concern and support for policies related to the growing climate change concern. During this decade, the UK government enacted energy policies and supports favorable to community energy projects, such as FIT schemes, leading to significant growth in the number of CEC. According to Community Energy England (2018), around 228 CEC organizations were active in England, Wales and North Ireland in 2017; this significant growth in the community energy sector may be attributed to the FIT scheme. Growth in community sectors resulted in the rise of the renewable energy capacity of the UK. The UK's community energy generation capacity grew from less than $50 \mathrm{MW}$ in the late 2000s to $249 \mathrm{MW}$ (including an estimated $81 \mathrm{MW}$ from Scottish CECs) in 2017; within England, Wales, and Northern Ireland CECs generate 80\% of their energy from solar, 18\% from wind and less than 1\% from hydro-electric (Community Energy England, 2018; Energy Saving Trust, 2019). In England, Wales, and North Ireland, community energy groups primarily generate solar energy, followed by wind energy. Whereas the majority of Scottish community energy generation comes from wind energy due to the high winds in northern Scotland (Braunholtz-Speight et al., 2018).

The FIT scheme permitted revenue payments to energy generators when energy was injected into grids; therefore, allowing the possibility for small energy generators to earn revenue by contributing to a significantly larger energy market (Mirzania, Ford, Andrew, Ofori, \& Maidment, 2019). The FIT scheme accelerated the growth of community energy enterprises, particularly after these schemes were approved for CECs with energy generation of up to 5 MW capacity (Braunholtz-Speight et al., 2018). The traditional business models of CECs in the UK are based on small-scale renewable energy projects up to $5 \mathrm{MW}$ where photo-voltaic panels or windmills are hosted by partner organizations like schools, civic bodies, and community centers. These partner organizations receive a discounted electricity supply, while the remaining majority of the energy is injected into power grids to generate revenue under the FIT scheme (Mirzania et al., 2019). The profit generated from the renewable energy is distributed to community members who invested in the CEC, and a specific portion of the profit is re-invested back to local communities that are part of the community development fund (Hiteva, \& Sovacool, 2017; Vancea et al., 2017). The traditional business model provided long-term visibility of the revenue stream, and this model was replicated by many community groups across the UK to set up new renewable energy projects (Regen, 2019).

The political environment changed in the UK with the 2016 national elections. These elections saw the rise of parties with neoliberalist ideologies supporting open market policies, ultimately leading the UK government to reverse its support for FITs and the withdrawal of other grants and subsidies (Braunholtz-Speight et al., 2018). Starting in 2015, the UK government has been gradually divesting its FIT responsibilities and payments, the goal of which is a complete withdrawal of FIT subsidies by 2019 (Green Alliance, 2019; Mirzania et al., 2019). After April 1, 2019, new community energy projects are no longer eligible for the FIT scheme, while existing community projects will continue to receive benefits until they reach the 20 years of the agreed support term. The implication of the FIT reversal is a decline in community energy sector growth and a lack of long-term visibility on policy matters, creating a sense of instability within community energy groups (Mirzania et al., 2019).

The implementation of the FIT scheme resulted in a golden period for the UK's community energy sector; however, the number of community-led projects fell after the reductions in FIT tariffs; a further decline in the number of CECs are expected after complete removal of FIT in 2019 (Hewitt et al., 2019). FIT removal has impacted the development and growth of CECs (Braunholtz-Speight et al., 2018; Eadson \& Foden, 2019). Community Energy England (2018) reported that between 2016 and 2017, 66 CEC projects stalled in England, Northern Ireland, and Wales; around 50\% of such cases resulted from the removal of FIT. Further, the removal of the FIT scheme has rendered the traditional community energy business model non-viable for smaller generators 
of up to $5 \mathrm{MW}$ and hampered the growth of the sector in the UK. Due to the market-driven policy regime, the UK's community energy market share remains significantly low; six big energy companies capture more than $90 \%$ of the market (Markantoni, 2016). The CECs share is around 1\% of the UK's total renewable energy generation capacity (Braunholtz-Speight et al., 2018).

\subsection{Roles and Motives}

As part of the energy transition strategy, European countries envision citizen-led, democratically governed renewable energy systems (Saintier, 2017). The UK's Department of Energy and Climate Control (2015) has recognized the critical role of community energy groups in achieving low carbon transition through grassroots initiatives. However, the transition to a low-carbon energy system is not without its challenges. The low-carbon-energy transition process is entangled between social practices, institutional arrangements, and renewable technologies (Geels et al. 2016). Therefore, it poses significant socio-technical challenges. The challenges are not insurmountable, and community energy groups can overcome these by having a participatory approach at the grassroots level (Van Der Schoor, Van Lente, Scholtens, \& Peine, 2016).

$\mathrm{CECs}$ are in a better position relative to large profit-making energy companies to disseminate sustainable practices and increase the adoption of low carbon technologies through citizen engagement (Herbes, Brummer, Rognli, Blazejewski, \& Gericke, 2017). Large energy companies based on fossil fuels and nuclear energy lack incentives to work in areas of energy efficiency and energy-saving measures as such services require consumer engagement at the grassroots level (Herbes et al., 2017). Further, large energy companies still consider energy as a tradable commodity and downplay the importance of citizen engagement for low carbon transition at the grassroots level. Renewable energy generation is the primary function of CECs; they also take active roles in sustainability-related projects in their local communities (Saintier, 2017). CECs act as sustainable entrepreneurs who co-create new societal regimes, co-evolve new institutional arrangements and develop new markets in their objective to achieve sustainable goals (Gasbarro, Annunziata, Rizzi, \& Frey, 2017). CECs, as social entrepreneurs, have both profit and non-profit motives (Becker et al., 2017). In their role as a social community group CECs work towards developing energy-savings and promoting sustainable practices in local communities through community engagement (Vancea et al., 2017). They bring transparency in energy pricing and reduce information asymmetry in the energy market, thereby building credibility and trust within the local community (Huybrechts \& Mertens, 2014). These attributes are indicative of a social enterprise with a focus on community grassroots involvement. However, CECs are not a purely non-profit enterprise; they are still responsible for ensuring a return on investment for the community members who have invested in community projects. Consequently, CECs with both profit and non-profit motives support energy transition and sustainable development.

Community energy is seen as a strategic tool for the low-carbon transition; due to open and participatory initiatives, CEC proponents see community energy as an alternative to the centralized and traditional energy system (Wyse \& Hoicka, 2019). In addition to green energy generation, CECs render the following benefits 1) democratic governance, 2) energy justice, 3) grassroots innovations, and 4) stimulate local economies by re-investing their profits. Collective ownership of energy systems based on the principle of democratic governance is the main idea behind community energy (Saintier, 2017). The cooperative model of CECs promotes democratic governance by involving community members in the decision-making process (Wyse \& Hoicka, 2019). Lack of transparency in energy price structure and poor consumer engagement also contributed to the emergence of community energy groups (Huybrechts \& Mertens, 2014). Large energy companies driven by profit motives do not reduce energy costs; therefore, they fail to address energy justice and fuel poverty issues. Conversely, CECs driven by sustainability missions, address issues related to fuel poverty, and employ energy efficiency steps through community engagements (Saintier, 2017).

Guided by a social mission, CECs develop bottom-up solutions to create social, economic, and ecological values for local communities (MacArthur, 2017; Vancea et al., 2017). This is the main benefit of community energy groups. CECs act as social entrepreneurs and grassroots innovators to create values for local communities (Becker et al. 2017). In the role of grassroots innovator, CECs resolve social and environmental issues with technological or social innovation when they engage local societies, local authorities, and research institutes in this innovation process (Seyfang, Hielscher, Hargreaves, Martiskainen, \& Smith, 2014). As grassroots innovators, CECs create new institutional arrangements and develop new technical solutions to challenge current regimes (Smith, Hargreaves, Hielscher, Martiskainen, \& Seyfang, 2016). Local embeddedness is another benefit in community energy initiatives. CECs focus on the local community in their actions related to sustainable developments (Prehoda, Winkler, \& Schelly, 2019). Especially in the UK, as per the Community Benefit Society Act of 2014, CECs are required to re-invest their profits into the local community to support sustainable developments. Community groups with the UK's hybrid ownership structure create new assets to benefit local 
communities (Hiteva \& Sovacool, 2017). CECs also benefit local communities by stimulating the economy. CECs retain the cost of energy within the community by having local generation and consumption; therefore, supporting the economy at local levels (Huh, Yoon, \& Chung, 2019).

\subsection{Organizational Structures}

Most CECs are governed by the one member, one vote mechanism irrespective of shareholding patterns of community members (Becker et al., 2017). The general ownership structure of CEC is based on the cooperative model. The importance of this ownership structure is that CECs have the potential to support the low-carbon transition by deploying small scale renewable energy systems and creating social, environmental, and economic values through community engagement. Similar to other European countries, Community Energy in the UK is a pluralistic sector that involves different types of social actors, motivations, and technologies (Seyfang et al., 2014).

The three types of community energy ownership structures prevalent in the UK are 1) Community Benefit Societies (CBS), 2) Community Interest Companies (CIC), and 3) bonafide cooperative model. The UK's Community Benefit Society Act of 2014 mandated all CECs register as CBS with an objective to 1) achieve growth and scalability in their operations and 2) reinvest their profits into the local community (Braunholtz-Speight et al., 2018). Prior to 2014, the ownership structure of the UK's CECs had been a bonafide cooperative model. However, since then, there has been a shift toward hybrid structures involving strategic partners and private developers (Saintier, 2017). The shift is in ownership structure is in response to changing market conditions and the need to promote scalability and expansion to new geographical locations. The two primary goals in shifting towards a hybrid governance structure are to 1) encourage entrepreneurship practices, and 2) achieve greater involvement in commercial-scale projects.

According to Community Energy England (2018), CBS is the most prevalent form of ownership structure used by $47 \%$ of CECs, while $19 \%$ of CECs used the traditional cooperative model, and $17 \%$ used the CIC ownership structure. The CBS differ from a bonafide cooperative in two important ways; first, the CBS structure primarily focuses on the benefit of society, whereas cooperatives work for the benefit of just members. The second, profits in cooperatives are shared between all members while in CBS, surplus money is re-invested back into society. There are many similarities between CICs and CBSs; they both focus on social value creation and re-invest their profits into the local communities to create a positive social impact (Hiteva \& Sovacool, 2017). Both the CBS and CIC act autonomously, have social and environmental value creation as a primary motive; also, both structures apply the asset lock mechanism to safeguard individual members. The main point of difference between the CIC and CBS ownership structure is that the CIC allows community groups to invest in commercial-scale renewable energy projects while maintaining a cooperative culture of one member one voting (Saintier, 2017). Both the CBS and CIC business structures can help CECs to adopt entrepreneurial and innovative practices in their business offerings (Braunholtz-Speight et al., 2018). The UK government proposed the hybrid ownership structures such as CBS and CIC in place of bonafide cooperative structures intending to frame CECs as a community enterprise. We believe these hybrid ownership structures are a positive move towards the development of the community energy sector. However, such hybrid organizations without low-interest financing options, entry to the marketplace, and support ecosystems may not achieve anticipated outcomes.

\subsection{Regional Differences}

Community energy development depends on the energy transition pathways adopted in that region. A significant variation in the community energy sector growth can be observed even in socially and geographically alike countries of western Europe. The energy transition strategy of European countries is diverse and depends on selected transition pathways. The UK's energy transition strategy is based on a transformation pathway where incumbent actors with policy supports are allowed to develop large-scale renewable energy systems; while, new entrants in this pathway are expected to compete with incumbents (Geels et al., 2016). In contrast, Germany's energy transition strategy is based on a technological substitution pathway, which supports civil societies and cooperatives to deploy decentralized renewable energy systems (Geels et al., 2016). The transition strategy related to the energy market also varies significantly between European countries. Germany and Denmark use coordinated market strategies by involving local actors and communities in decision making; conversely, the UK, Belgium, and the Netherlands rely on market-driven competitive strategies that lead to incongruence with regional and local community organizations (Creamer et al., 2018). Understandably, the UK's energy policy support is less favorable to CECs than that of Germany or Denmark. Local actors serve as intermediary bodies to bridge policy gaps by fostering collaborations and building consensus at local levels across the UK.

CEC growth within the UK has been dissimilar at the regional level. The asymmetrical performance of 
community energy groups within the UK member states illustrates the differing interventions at the grassroots level. Community energy has achieved significant growth in the devolved governments of the UK, especially in Scotland (Strachan et al., 2015). Through the Community and Renewable Energy Scheme (CARES), Scotland provides local support to community energy. However, such local interventions in CEC support are not visible in England and North Ireland. The political devolution permitted Scottish policymakers to provide funding and create new opportunities for community energy (Markantoni, 2016). Development supports and public financing during the planning stage are essential for sector growth. CARES, set up by the Scottish government as part of a local intervention, provides such support and financing by allocating funds towards feasibility and pre-planning renewable community schemes (Strachan et al., 2015). Local Energy Scotland (LES) has been providing CARES supports and funds on behalf of the Scottish government since 2013; under the current policy uncertainty, LES has developed new solutions with local community groups to improve their viability (Local Energy Scotland, 2016). To address project financing issues, CARES teams collaborate with sustainability leaning banks to increase investments in the Scottish community energy sector (Local Energy Scotland, 2016). However, such community energy development funding from public institutions are not readily available in England and North Ireland.

While we review the regional growth of the community energy sector, it is also interesting to explore community energy developments in North America, especially Canada, that predominantly rely on fossil fuel-based energy systems. Like the U.S., Canadian provinces have constitutional jurisdiction to enact and implement their energy policies; at the national level, there is no community energy policy with a specific focus on the local cooperatives (MacArthur, 2017). Through local initiatives, Canadian provinces support community energy; local actors like city councils and municipalities are major actors in strategic planning for local energy systems (Wyse \& Hoicka, 2019). In the Ontario province, through the Green Energy Act (2009), FIT schemes are used as instruments to promote community energy development, while community energy policy supports are less visible in other provinces (MacArthur, 2017). Due to electoral polities, energy policy uncertainty and reversals are common in both Canada and the UK (MacArthur, 2017). Although energy policies in the UK and Canada are enacted by national and provincial governments respectively, we can still draw the following common elements related to community energy sectors in both countries 1) the application of FIT schemes as an instrument, 2) policy uncertainty and reversal, and 3) the use of local actors to fill-in any policy gaps. In the following section, we discuss the problems and issues faced by CECs in their endeavor to provide an option for the low-carbon energy transition.

\subsection{Problems and Issues}

CECs face different types of problems that include 1) the removal of subsidies, 2) lack of funds during the feasibility study and high-interest rates for project financing, and 3) lack of dedicated and skilled professionals. Additionally, smaller renewable energy generators compete with big energy companies in an open market (Hall, Foxon, \& Bolton, 2016). In the last five years, policy changes leading to a reversal of FIT supports and other subsidies have necessitated that CECs explore new financial instruments and business ventures to remain viable. Furthermore, the CEC's cooperative structure does not permit managers to apply entrepreneurial skills to create new opportunities and take risks (Morrison, Ramsey, \& Bond, 2017).

The limited source of public funding for feasibility studies is a common concern as most CECs explore external fundings from local authorities and intermediary organizations (Community Energy England, 2018). CARES, set up by the Scottish government as part of the local intervention, provides funds towards feasibility and pre-planning of community-renewable schemes (Strachan et al., 2015). The Wales government, through a country-specific funding initiative, Ynni Lleol, provides expertise and financial support to communities and small businesses (Community Energy England, 2018). However, the deployment of similar public funding sources is not readily available in England and North Ireland.

Another business problem that CECs in the UK face is the lack of regular and skilled professionals who can understand the energy policy landscape and develop informed and necessary strategies on behalf of their community groups. Understandably, CECs based on a cooperative structure cannot hire a high-salaried business professional to run their organizations; instead, they rely on volunteers driven by altruistic motives. The community energy policy support in the UK overlooks issues related to the lack of regular and skilled professionals required for community energy growth (Strachan et al., 2015). The CECs in the UK face a shortage of business professionals to manage operations and finances, and therefore, they depend on intermediary organizations (Seyfang et al., 2014).

The traditional CEC business models based on a small-scale generation of up to $5 \mathrm{MW}$ capacity relying on the 
FIT supports are no longer viable in a subsidy-free regime. Additionally, the falling costs of renewable energy from solar panels and windmills make small-scale generations a non-viable option. The traditional business model of CECs is largely focused on the energy generation side, and since this is no longer feasible, CECs must explore the supply side initiatives such as energy efficiency and demand-side responses for new value creation (Braunholtz-Speight et al., 2018). Large-scale solar farms based on shared ownership models with private developers are a favorable option for CECs post FIT removal (Community Energy England, 2018). Researchers have attributed the lack of a supportive environment as the root of current business problems faced by CECs in the UK. Support strategies are critical for the growth of CECs; Germany's Energiewende strategy and its support environment can be attributed to the success of community energy growth (Hall et al., 2016). In contrast, through market-driven policies, the UK government wants to permeate entrepreneurial and innovative practices in CECs. This way, these niche organizations can become involved in the competitive market through new business models (Eadson \& Foden, 2019). Consequently, the current policy support remains inadequate to enable niche organizations to compete with large incumbents. Therefore, with the open market in mind, the UK policymakers must develop and support the business ecosystem of CECs in the UK. Developing a renewable energy business ecosystem requires 1) building new institutional arrangements, 2) creating market demands through new policies and regulations, and 3) providing supports for knowledge and capabilities at the grassroots level (Suri, 2017)

\section{The Removal of FITs in the UK}

\subsection{Rationale for FITs Removal}

Currently, the UK's energy policies are anchored in the market liberalization concept. The UK envisions future energy systems driven by open, democratically governed, and competitive markets (Braunholtz-Speight et al., 2018; Creamer et al., 2018). The UK aimed to create a new market logic in 2014 by proposing CECs as a means to improve market competition and lessen the dominance of big energy companies (Eadson \& Foden, 2019). However, political change in 2016 saw a shift in UK energy policies towards market-based neoliberal ideas (Hall et al., 2016). This change in policy has had significant implications for CECs. In particular, the implications of market-focused energy policies on CECs include higher interest rates on project financing and barriers to entry in existing energy markets dominated by large incumbents. Additionally, large incumbents with existing energy infrastructure and resources have a cost advantage and higher risk appetite in a market-based policy regime. The high barriers to entry are further compounded by the difficulty CECs face in securing financing. In a market-based environment, financial institutions lack incentives to provide low-interest financing to CECs; therefore, CECs are likely to remain niche organizations unless there is a change in existing financing arrangements (Hall et al., 2016).

The UK government views CECs as market-oriented community enterprises (Braunholtz-Speight et al., 2018). As a way to usher in market-based practices, the UK government withdrew FITs and grants to encourage CECs as a new form of community enterprises to take part in the open market (Eadson \& Foden, 2019). The UK reduced FITs and subsidies to CECs intending to empower them to grow as a self-sustaining enterprise (Green Alliance, 2019). The UK government proposed the hybrid ownership structures such as CBS and CIC in place of bonafide cooperative structures intending to frame CECs as a community enterprise. We believe these hybrid ownership structures are a positive move towards the development of the community energy sector. However, such hybrid organizations without low-interest financing options, the dedicated marketplace, and support ecosystems may not achieve anticipated outcomes.

\subsection{UK's Regional Response to FIT Removal}

The regional response to FIT removal in the UK varies widely between the four-member states England, Scotland, Wales, and North Ireland. In contrast to England and North Ireland, the devolved states of Scotland and Wales, through their political devolution rights, devised new strategies to offset the impact of subsidy withdrawal in the community energy sector. In response to subsidy removal, Scotland and Wales proposed new community energy strategies that include 1) an element of community ownership in all the renewable project post-2020, 2) local energy planning, 3) focus on creating local energy markets, and 4) low-interest project financing through development banks (Local Energy Scotland, 2016; Regen, 2019; Scottish government, 2017). In its energy strategy, the Wales government created new opportunities for community groups by proposing a shared ownership route to increase local participation. From 2020, all renewable energy projects in Wales will have community ownership of 5\% to $33 \%$; also, in this shared ownership, the project developer will attract relief on property rents equivalent to community ownership percentage in shared ownership (Regen, 2019). Additionally, through local actors and innovators, the Wales government has initiated pilot projects to explore financially viable local energy markets such as long-term Power Purchase Agreement (PPA) and peer-to-peer trading. Under the new strategies, communities have priority bidding for renewable energy projects on public lands; and also, the opportunity to 
obtain low-interest financing from development banks (Regen, 2019).

Compared to other regions of the UK, available data from Scotland shows subsidy removal at the national level did not have any significant impact on Scottish community energy from 2016 to 2019. Energy Saving Trust (2019) reported community energy operational capacity grew at 3\% compared to 2018; five shared ownership model-based community projects obtained approval, and another 46 shared ownership projects were under discussion. The Scottish Government (2017) stated we want a significant increase in shared ownership-based community projects, this will be putting energy into the hands of local communities and deliver a lasting economic asset across Scotland. The Scottish government also highlighted that using a shared ownership model, we can achieve $2 \mathrm{GW}$ of community and locally-owned energy targets by 2030. During the uncertainty following the removal of the FIT incentives, the Scottish Government committed to supporting the community energy sector by allowing shared ownership in new renewable energy projects (Energy Saving Trust, 2019). As part of the 2050 energy vision, the Scottish government (2017) highlighted the need for partnerships involving the local government, private sector, trade bodies, and community groups that will help to address any tensions and trade-offs and maximize the benefit for Scotland. Having discussed the rationale behind FIT removal and regional response to this, we discuss emerging business practices in the following section.

\section{Discussion}

The removal of the FIT scheme and other subsidies have adversely impacted the interests of community energy groups who plan to build and operate renewable energy projects of up to 5MW capacity. In the UK's market-driven energy regime, the existence of community energy remains bleak unless new strategies are formulated in their support. Within the UK's member states, there has been a diverse response to subsidy removal. While in England, community energy groups, without government support, struggle to remain viable and achieve growth; conversely, devolved states Scotland and Wales have locally intervened in favor of these community groups. In the following sections, we discussed three emerging business concepts that can help CECs to remain profitable and grow in the UK's subsidy-free environment.

\subsection{Shared Ownership Model}

During our review, evidence from Scotland, Wales, and Germany indicated that renewable energy projects based on a shared ownership model involving community groups and private developers were an important part of a successful community energy strategy. Through their devolved rights, Scotland and Wales have ensured the involvement of community groups in all the new renewable projects under a shared ownership model. With the removal of the FIT scheme and falling costs of renewable energy, small scale energy generation is no longer viable for CECs; therefore, large-scale renewable energy projects in a shared ownership model can bring much-needed revenue visibility for CECs (Willis \& Simcock, 2019). Also, community energy groups see advantage in partnering with private developers due to their project experience and risk management knowledge on large scale renewable energy projects (Saintier, 2017). The shared ownership model has emerged as a preferred option for community energy groups in Germany; CECs partner with private developers in hybrid structures to reduce risks and increase chances of success (Hewitt et al., 2019).

In 2017, there were 40 shared ownership projects in Scotland; the ownership stake of local communities ranged between $10 \%$ to $30 \%$ (Green Alliance, 2019). In these shared ownership arrangements, community groups can have democratic control over assets and continue to work for sustainable development activities. Shared ownership exists in a variety of ways that includes joint ventures, split ownerships, and shared revenue models, however, CECs should choose the most appropriate model based on investment capacity and risk appetite (Green Alliance, 2019), The UK government took a welcome step in 2014 when they proposed hybrid structures such as CIC and CBS with the intention of framing community energy groups as community enterprises; the objective of this hybrid structure was to empower CECs to work in commercial-scale projects across the UK. However, CBS and CIC structures alone can't transform CECs into a community enterprise unless a suitable business ecosystem is created around them.

\subsubsection{Recommendations for Business Practice 1}

In our analysis, we found a shared ownership model can benefit community groups in two ways 1) provides long-term visibility on the revenue stream, and 2) reduces investment risk. Shared ownership models are just developing in the UK. In this type of institutional arrangement, community energy groups, commercial developers, and intermediaries create a venture to build new assets (Mirzania et al., 2019). A new form of hybrid structure, like a shared ownership model between community energy groups and commercial developers, can ensure the success of community projects in a subsidy-free environment (Prehoda et al., 2019). Community Energy England (2018) reported that several CECs had chosen shared ownership with public and private 
developers as a lower risk route; CIC companies like 'Community for Renewable' in England helped communities get involved in commercial solar farms and collaborated with social bank to secure funding. Based on our analysis, we recommend all CECs in the UK explore the feasibility of setting up new projects based on a shared ownership model that can improve business viability and reduce the operational risk in a subsidy-free environment.

\subsection{Mix of Top-down policy and Bottom-up Initiatives}

Shared ownership can provide much-needed revenue visibility to community groups; however, hybrid structures alone can't help CECs to achieve the full potential of sustainability development unless an engaging and practice-based support system is created. A top-down policy approach without consideration for non-state actors and their practices at the grassroots level is detrimental for CEC growth. The UK's present national energy policy is mostly based on a top-down approach without any room for local elements in the decision-making process (Fudge, Peters, \& Woodman, 2016). The success of the UK government's top-down policy approach depends on non-state actors who narrow the policy gaps through collaboration and shared information (Markantoni, 2016). Policymakers in the UK assume that the top-down approach is sufficient to achieve energy transition without any focus on energy practices and available resources at the regional level (Sait, Chigbu, Hamiduddin, \& de Vries, 2019). The implication for the top-down policy includes depriving required support to CECs in planning and identifying potential business opportunities in their local areas. When local actors are engaged in planning processes, they can support CECs through collaborations, shared knowledge, and use social capital (Hiteva \& Sovacool, 2017). If CECs are to benefit from energy policies, then the policies must align with community resource availability and their energy needs at the regional level; otherwise, the CECs will fail to achieve their intended objectives (Sait et al., 2019).

Within the UK, local actors play an essential role in supporting CECs. In Scotland, LES, a body formed by the Scottish government, collaborates with authorities to enable CECs to achieve their full potential (Strachan et al., 2015). While in England, intermediary organizations come forward in support of CECs (Seyfang et al., 2014; Smith et al., 2016). Smith et al. (2016) defined local actors as an intermediary organization in the UK who facilitate collaboration between groups and provide support services for their projects. Intermediary organizations exist in different forms and are represented by citizen groups, trusts, or city councils at the local level (Seyfang et al., 2014). In the UK, local city councils and civic bodies act as intermediary agents who create a network of actors within the business ecosystems of CECs (Fudge et al., 2016). In their attempt to create a CEC business ecosystem, intermediary organizations collaborate with government agencies and research institutions to drive the development of CECs (Surie, 2017). Intermediary organizations in the UK help under-resourced CECs by providing business advice on dealing with the persistent energy regime, technical knowledge, and skilled resources to supervise the day-to-day administrative work (Braunholtz-Speight et al., 2018).

Like Scotland, Germany also recognizes the assemblage of local actors in the decision-making process related to the energy transition strategy called "Energiewende" (Sait et al., 2019). As part of the Energiewende strategy, policymakers use a mix of top-down policy and bottom-up initiatives to make new institutional arrangements to accommodate a network of local actors (Moss, Becker, \& Naumann, 2015). The Energiewende strategy of Germany permits the involvement of local actors who, in turn, drive renewable energy growth (Hoppe, Graf, Warbroek, Lammers, \& Lepping, 2015). Through bottom-up initiatives, local actors create supportive environments for social and business model innovations (Hiteva \& Sovacool, 2017).

The business ecosystem is not about just two actors (government and entrepreneur). It also involves other actors like social enterprises, universities, and the non-profit sector, all of which have a common responsibility to develop a supporting business environment (Scaringella \& Radziwon, 2018). Guided by the climate change agenda, local authorities in the UK are actively taking part in energy governance; this can create a new window of opportunity for CECs (Fudge et al., 2016). In the current unfavorable policy environment, CECs can collaborate with these intermediary organizations within local cities or at the regional level to explore new business opportunities (Community Energy England, 2018). Scaringella and Radziwon (2018) discussed the territorial business ecosystem at the regional level. They suggested interconnections and interdependencies between local actors of the ecosystem help create a trusting business environment using social capital and shared knowledge. Collaboration and support at a regional and local level driven by intermediary organizations are central in stimulating CECs growth in the UK (Community Energy England, 2019). In conclusion, intermediary organizations in the UK play an important role in the development of the community energy sector. Although these intermediaries are not directly involved in energy generation and sustainability development, they are the key elements of the business ecosystem of community energy in the UK. 


\subsubsection{Recommendations for Business Practice 2}

In our analysis, we observed a mix of the top-down policy and the bottom-up initiative was a critical factor in the successful energy transition strategies of Germany and Scotland. The traditional top-down approach is less effective in a complex social-technical system like energy transition (Creamer et al., 2018). The participatory practice can drive greater policy uptake and reduce resistance from social actors in community energy projects (MacArthur, 2016). The participatory practice is the main idea behind the conceptualization of CECs where citizen groups, city councils, and municipalities with their knowledge of the energy needs and local resources can create new investment opportunities (Wyse \& Hoicka, 2019). The Scottish Government (2017) visualized an integrated approach towards future energy systems that covers all geographical areas and supports partnership arrangements between communities, local authorities, and private sectors.

Faced with climate concerns and a need to achieve carbon neutrality, most city councils and municipal bodies in England are willing to initiate sustainable development and renewable energy projects. Using a collaborative approach, CECs can create local energy markets when they make Power Purchase Agreement (PPA) with local authorities; in the absence of FIT support, such agreements can result in long-term revenue visibility (Eadson \& Foden, 2019). In a FIT free environment, CECs can partner with local energy suppliers to forge new business models for the local energy sale instead of selling through grids (Willis \& Simcock, 2019). Community Energy England (2018) reported the 'Zero West' initiative by Bristol Energy Co-operative in 2017 aims to accelerate the low carbon transition in the West of England through collaboration between communities, local authorities, developers, and technology providers. Based on our analysis, we recommend CECs in the UK to collaborate with city councils and civic bodies to create opportunities through new business models.

\subsection{Access to Project Finance}

The FIT scheme provided long-term revenue visibility to CECs to plan and re-invest their profits into sustainability initiatives. Post FIT removal, it is essential for CECs to have low-interest financing options available to fund their projects. Without additional support mechanisms, the market-based finance instrument will increase the risk and reduce the profit margins of CECs; therefore, new financial models are required to enable the CECs to grow and develop new projects (Regen, 2019).

Comparing the financial support arrangement in the UK and Germany's energy transition pathways highlights the difference in how each country engaged in community energy projects. The UK's energy transition path relied on competition and market-based high-interest financial instruments (Hall et al., 2016). Conversely, in Germany, a coordinated market, and availability to low-interest financing in the civil energy sector resulted in a higher sustainability energy transition path (Hall et al., 2016). Similar to Germany, the devolved member states of Scotland and Wales provide low-interest funding to community projects. The Scottish Government (2017) setup the Renewable Energy Investment Fund (REIF) in 2012 to finance renewable community projects; since then, the Fund has invested $£ 60$ million to supported community groups secure business deals.

\subsubsection{Recommendations for Business Practice 3}

We also observed the lack of low-interest finance required during the feasibility and project stage is a significant issue faced by most CECs in the UK. CECs can explore innovative low-interest financing models with the help of intermediary organizations and social enterprise banks. Crowdfunding platforms for retail investors could be a useful source of financing community projects (Dilger, Jovanović, \& Voigt, 2017). Local Energy Scotland (2016) highlighted that the CARES support team collaborates with Triodos Bank to provide low-interest financial solutions for CECs to progress on projects. Many social enterprise banks are willing to provide low-interest financing through retail investors for an economically viable renewable project in the UK. We recommend CECs collaborate with intermediary organizations to explore low-interest financing solutions through these banks.

\subsection{Discussion Summary}

The UK's current energy policies, based on the market liberalization concept, foresee energy systems driven by an open and competitive market (Braunholtz-Speight et al., 2018). In this uncertain policy regime, we observed three business concepts that can help CECs to improve business viability. First, we found the shared ownership model-based community energy projects can provide revenue stream visibility on a long-term basis. Also, CECs can reduce their investment risks in these institutional arrangements. While a shared ownership model can improve the business viability of CECs, however, this comes with its problems. CECs relying on part-time volunteers must seek support from intermediary organizations on business issues and negotiation skills to safeguard their interests. Second, a mix of top-down policy with a bottom-up initiative can bring more value to CECs when they collaborate and partner with local actors such as the city council and municipalities who are 
part of the business ecosystem (Surie, 2017). Third, we observed that Scotland and Wales, through their renewable energy funds and development banks, provide low-interest project funding to CECs. However, such public fundings are not available in England and North Ireland; therefore, CECs in these member states should explore low-interest finance solutions utilizing their business ecosystem. Having discerned business concepts that are important in improving the business viability of CECs, we have recommended three business practices.

\section{Conclusion}

In this paper, we explored the implications of FIT support removal in the UK's community energy sector and made three recommendations for business practices that CECs in the UK should consider to remain profitable and grow in the era of competitive market energy policies. The three recommendations are 1) take part in shared ownership projects, 2) collaborate with local actors for bottom-up initiatives, and 3) explore low-interest financing models within the business ecosystem. Encouraging collaborations and partnerships between CECs, city councils, and private developers, can create a space for innovations and entrepreneurship at the local level; such business practices can unleash CEC's true potential. Using such business practices, CECs in the UK can improve their business viability and achieve growth under the present market-driven policy regime.

We also observed that Canada's community energy sector is just evolving, where policy supports lack cohesiveness and are largely depend on provincial jurisdictions. In our review, we observed common elements related to the community energy sector between the UK and Canada: 1) use of the FIT scheme, 2) policy uncertainty and reversal, and 3) the role of local actors in filling-up policy gaps. This paper can impart new knowledge to CEC managers in Canada that could help them understand the implications of subsidy removal and prepare them to apply new business practices in a subsidy-free environment.

This paper highlighted a gap related to practices and policy supports for community energy between the member states of the UK. Keeping FIT removal in mind, we aim to provide insight and recommendations to the UK's policymakers about how to create a favorable environment for CECs in a market-driven policy regime. We observed that participatory practices and citizen engagement are an essential feature of a decentralized and democratically governed energy systems. These features can bring new opportunities for CECs; therefore, we recommend accommodation of local actors and identification of their roles when developing community energy strategies. Finally, we showed the potential of shared ownership models and the necessity of making the community group's participation compulsory in all new renewable energy projects as part of a UK's community energy strategy.

\section{References}

Becker, S., Kunze, C., \& Vancea, M. (2017). Community energy and social entrepreneurship: Addressing purpose, organisation and embeddedness of renewable energy projects. Journal of Cleaner Production, 147(1), 25-36. https://doi.org/10.1016/j.jclepro.2017.01.048

Braunholtz-Speight, T., Mander, S., Hannon, M., Hardy, J., McLachlan, C., Manderson, E., \& Sharmina, M. (2018). Evolution of community energy in the UK. Retrieved from http://www.ukerc.ac.uk

Community Energy England. (2018). Community energy state of the sector 2018 full report. Retrieved from https://communityenergyengland.org/pages/state-of-the-sector-report-2018/

Community Energy England. (2019). Community energy state of the sector 2019 full report. Retrieved from https://communityenergyengland.org/files/document/317/1561208314_StateoftheSectorReport2019-FullRe port.pdf

Creamer, E., Eadson, W., van Veelen, B., Pinker, A., Tingey, M., Braunholtz - Speight, T., ... Lacey - Barnacle, M. (2018). Community energy: Entanglements of community, state, and private sector. Geography Compass, 12(7), 1-16. https://doi.org/10.1111/gec3.12378

Cropanzano, R. (2009). Writing nonempirical articles for journal of management: General thoughts and suggestions. Journal of Management, 35(6), 1304-1311. https://doi.org/10.1177/0149206309344118

Department of Energy and Climate Change (2015). Community energy strategy update. Retrieved from https://www.gov.uk/government/

Dilger, M. G., Jovanović, T., \& Voigt, K. I. (2017). Upcrowding energy cooperatives-Evaluating the potential of crowdfunding for business model innovation of energy cooperatives. Journal of Environmental Management, 198(1), 50-62. https://doi.org/10.1016/j.jenvman.2017.04.025

Eadson, W., \& Foden, M. (2019). State, community and the negotiated construction of energy markets: Community energy policy in England. Geoforum, 100, 21-31. 
https://doi.org/10.1016/j.geoforum.2019.02.006

Energy Saving Trust (2019). Community and locally owned renewable energy in Scotland at June 2019. Retrieved https://energysavingtrust.org.uk/sites/default/files/Community\%20and\%20locally\%20owned\%20renewable \%20energy\%20in\%20Scotland.\%202019\%20Report.pdf

Fudge, S., Peters, M., \& Woodman, B. (2016). Local authorities as niche actors: The case of energy governance in the UK. Environmental Innovation and Societal Transitions, 18, 1-17. https://doi.org/10.1016/j.eist.2015.06.004

Gasbarro, F., Annunziata, E., Rizzi, F., \& Frey, M. (2017). The interplay between sustainable entrepreneurs and public authorities: Evidence from sustainable energy transitions. Organization \& Environment, 30, 226-252. https://doi.org/10.1177/1086026616669211

Geels, F. W., Kern, F., Fuchs, G., Hinderer, N., Kungl, G., Mylan, J., ... \& Wassermann, S. (2016). The enactment of socio-technical transition pathways: A reformulated typology and a comparative multi-level analysis of the German and UK low-carbon electricity transitions (1990-2014). Research Policy, 45, 896-913. https://doi.org/10.1016/j.respol.2016.01.015

Gilson, L. L., \& Goldberg, C. B. (2015). Editors' comment: So, what is a conceptual paper?. Group \& Organization Management, 40(2), 127-130. https://doi.org/10.1177/1059601115576425

Green Alliance. (2019). Community energy 2.0 the future role of local energy ownership in the UK. Retrieved from https://www.green-alliance.org.uk

Hall, S., Foxon, T. J., \& Bolton, R. (2016). Financing the civic energy sector: How financial institutions affect ownership models in Germany and the United Kingdom. Energy Research \& Social Science, 12(2), 5-15. https://doi.org/10.1016/j.erss.2015.11.004

Herbes, C., Brummer, V., Rognli, J., Blazejewski, S., \& Gericke, N. (2017). Responding to policy change: New business models for renewable energy cooperatives-Barriers perceived by cooperatives' members. Energy Policy, 109, 82-95. https://doi.org/10.1016/j.enpol.2017.06.051

Hewitt, R. J., Bradley, N., Baggio Compagnucci, A., Barlagne, C., Ceglarz, A., Cremades, R., ... \& Slee, B. (2019). Social innovation in community energy in Europe: A review of the evidence. Frontiers in Energy Research, 7(31), 1-27. https://doi.org/10.3389/fenrg.2019.00031

Hiteva, R., \& Sovacool, B. (2017). Harnessing social innovation for energy justice: A business model perspective. Energy Policy, 107, 631-639. https://doi.org/10.1016/j.enpol.2017.03.056

Hoppe, T., Graf, A., Warbroek, B., Lammers, I., \& Lepping, I. (2015). Local governments supporting local energy initiatives: Lessons from the best practices of Saerbeck (Germany) and Lochem (The Netherlands). Sustainability, 7, 1900-1931. https://doi.org/10.3390/su7021900

Huh, T., Yoon, K. Y., \& Chung, I. R. (2019). Drivers and ideal types towards energy transition: Anticipating the futures scenarios of OECD countries. International Journal of Environmental Research and Public Health, 16(8), 1-16. https://doi.org/10.3390/ijerph16081441

Huybrechts, B., \& Mertens, S. (2014). The relevance of the cooperative model in the field of renewable energy. Annals of Public and Cooperative Economics, 85, 193-212. https://doi.org/10.1111/apce.12038

Kahn, S., \& Zeidler, D. L. (2017). A case for the use of conceptual analysis in science education research. Journal of Research in Science Teaching, 54(4), 538-551. https://doi.org/ 10.1002/tea.21376

Koirala, B. P., Chaves Avila, J. P., Gómez, T., Hakvoort, R. A., \& Herder, P. M. (2016). Local alternative for energy supply: Performance assessment of integrated community energy systems. Energies, 9, 981-1005. https://doi.org/10.3390/en9120981

Local Energy Scotland. (2016). CARES progress and impact. Retrieved from https://www.localenergy.scot/media/96610/CARES-Progress-and-Impact.pdf

MacArthur, J. L. (2016). Challenging public engagement: participation, deliberation and power in renewable energy policy. Journal of Environmental Studies and Sciences, 6(3), 631-640. https://doi.org/10.1007/s13412-015-0328-7

MacArthur, J. L. (2017). Trade, tarsands and treaties: The political economy context of community energy in Canada. Sustainability, 9(3), 464. https://doi.org/10.3390/su9030464 
Markantoni, M. (2016). Low carbon governance: mobilizing community energy through top - down support?. Environmental Policy and Governance, 26, 155-169. https://doi.org/10.1002/eet.1722

Mirzania, P., Ford, A., Andrews, D., Ofori, G., \& Maidment, G. (2019). The impact of policy changes: The opportunities of community renewable energy projects in the UK and the barriers they face. Energy Policy, 129, 1282-1296. https://doi.org/10.1016/j.enpol.2019.02.066

Morrison, C., Ramsey, E., \& Bond, D. (2017). The role of social entrepreneurs in developing community resilience in remote areas. Journal of Enterprising Communities, 11, 95-112. https://doi.org/10.1108/jec-02-2015-0020

Moss, T., Becker, S., \& Naumann, M. (2015). Whose energy transition is it, anyway? Organisation and ownership of the Energiewende in villages, cities and regions. Local Environment, 20, 1547-1563. https://doi.org/10.1080/13549839.2014.915799

Prehoda, E., Winkler, R., \& Schelly, C. (2019). Putting research to action: Integrating collaborative governance and community-engaged research for community solar. Social Sciences, 8(11), 1-24. https://doi.org/10.3390/socsci8010011

Regen. (2019). How to protect, promote and achieve scale in community and local ownership of renewable energy in Wales. Retrieved from https://www.regen.co.uk/wp-content/uploads/IWA_Energy_WP4.1.pdf

Saintier, S. (2017). Community energy companies in the UK: A potential model for sustainable development in "local" energy? Sustainability, 9(8), 1-18. https://doi.org/10.3390/su9081325

Sait, M. A., Chigbu, U. E., Hamiduddin, I., \& De Vries, W. T. (2019). Renewable energy as an underutilised resource in cities: Germany's 'Energiewende' and lessons for post-brexit cities in the United Kingdom. Resources, 8(7), 1-27. https://doi.org/10.3390/resources8010007

Scaringella, L., \& Radziwon, A. (2018). Innovation, entrepreneurial, knowledge, and business ecosystems: Old wine in new bottles?. Technological Forecasting and Social Change, 136, 59-87. https://doi.org/10.1016/j.techfore.2017.09.023

Scottish Government. (2017). Scottish energy strategy: The future of energy in Scotland. Retrieved from https://www.gov.scot/publications/scottish-energy-strategy-future-energy-scotland-9781788515276/

Seyfang, G., Hielscher, S., Hargreaves, T., Martiskainen, M., \& Smith, A. (2014). A grassroots sustainable energy niche? Reflections on community energy in the UK. Environmental Innovation and Societal Transitions, 13(1), 21-44. https://doi.org/10.1016/j.eist.2014.04.004

Smith, A., Hargreaves, T., Hielscher, S., Martiskainen, M., \& Seyfang, G. (2016). Making the most of community energies: Three perspectives on grassroots innovation. Environment and Planning A, 48, 407-432. https://doi.org/10.1177/0308518X15597908

Strachan, P. A., Cowell, R., Ellis, G., Sherry - Brennan, F., \& Toke, D. (2015). Promoting community renewable energy in a corporate energy world. Sustainable Development, 23(2), 96-109. https://doi.org/10.1002/sd.1576

Surie, G. (2017). Creating the innovation ecosystem for renewable energy via social entrepreneurship: Insights from India. Technological Forecasting and Social Change, 121, 184-195. https://doi.org/10.1016/j.techfore.2017.03.006

Van Der Schoor, T., Van Lente, H., Scholtens, B., \& Peine, A. (2016). Challenging obduracy: How local communities transform the energy system. Energy Research \& Social Science, 13, 94-105. https://doi.org/10.1016/j.erss.2015.12.009

Vancea, M., Becker, S., \& Kunze, C. (2017). Local embeddedness in community energy projects. A social entrepreneurship perspective. Revista Internacional de sociología, 75(4), 1-12. https://doi.org/10.3989/ris.2017.75.4.17.03

Willis, R., Simcock, N. (2019) Consumer (Co-)Ownership of Renewables in England and Wales (UK). In Lowitzsch J. (Eds.), Energy transition (pp. 369-394). https://doi.org/10.1007/978-3-319-93518-8_17

Wyse, S. M., \& Hoicka, C. E. (2019). "By and for local people": assessing the connection between local energy plans and community energy. Local Environment, 24(9), 883-900. https://doi.org/10.1080/13549839.2019.1652802 


\section{Copyrights}

Copyright for this article is retained by the author(s), with first publication rights granted to the journal.

This is an open-access article distributed under the terms and conditions of the Creative Commons Attribution license (http://creativecommons.org/licenses/by/4.0/). 